\title{
Investigation of removal possibilities of chromium(III) oxide from water solution in the presence of albumins
}

\author{
K. Szewczuk-Karpisz • M. Wiśniewska
}

Received: 14 March 2014/Revised: 13 October 2014/Accepted: 10 November 2014/Published online: 25 November 2014

(C) The Author(s) 2014. This article is published with open access at Springerlink.com

\begin{abstract}
System destabilization is a highly desirable phenomenon during colloidal impurity removal from sewages and wastewaters. Therefore, in this study, the stability of chromium(III) oxide suspension in the absence and presence of albumins [bovine serum albumin (BSA), ovalbumin (OVA), human serum albumin (HSA)] was investigated. Based on the analysis of experimental results, i.e., measurements of adsorption amount, electrokinetic potential, and metal oxide surface charge density as well as system stability, the mechanism of the suspension stabilization/destabilization was proposed. The examined system without the albumins is relatively stable at $\mathrm{pH} 3,4.6$, and 9 (TSI $=34.8,36.6,34.22$, respectively), which is associated with the electrostatic stabilization phenomenon. In turn, the least stable is the suspension at $\mathrm{pH} 7.6(\mathrm{TSI}=55.43)$. This is the result of the adsorbent zero surface charge. Regardless of solution $\mathrm{pH}$, the BSA, OVA, or HSA adsorption causes an increase in the system stability $(17.55<$ TSI $<30)$. Probably, the steric stabilization is involved in this phenomenon, which results from the mutual repulsion of the adsorption layers formed on the solid surface. Thus, it can be concluded that the albumin presence in the industrial wastewaters impedes the chromium(III) oxide removal.
\end{abstract}

Keywords Albumin adsorption - Colloids - Electrostatic and steric stabilization $\cdot$ Zeta potential

K. Szewczuk-Karpisz $(\bowtie) \cdot$ M. Wiśniewska Department of Radiochemistry and Colloid Chemistry, Faculty of Chemistry, Maria Curie Sklodowska University, M. Curie Sklodowska Sq. 3, 20-031 Lublin, Poland

e-mail: k.szewczuk-karpisz@wp.pl

\section{Introduction}

Stable suspension is characterized by no macroscopic processes, such as observable separation of suspended particles and water. This means that even after a long time, the particles sedimentation will not be observed. High suspension stability is highly undesirable in wastewater treatment, especially during colloidal impurity removal. Then, settling tanks cannot effectively perform their task (Nowicki 2005). The polymer addition often changes the system stability. The most preferred phenomenon is the suspension destabilization. Macromolecular compound adsorption on colloidal particle surface changes the nature of interactions between solid particles. The low suspension stability is equivalent to the formation of large particle aggregates which fall on the reservoir bottom (Wiśniewska and Szewczuk-Karpisz 2013).

Contaminant removal from aqueous solutions is a research subject of many scientists (Gupta et al. 2012a). Of particular interest are methods for various dye removal, i.e., chrysoidine Y (Mittal et al. 2010), amaranth (Mittal et al. 2005; Gupta et al. 2012d), erythrosine (Gupta et al. 2006b), brilliant blue FCF (Gupta et al. 2006a), reactofix golden yellow (Gupta et al. 2007d), reactofix red (Gupta et al. 2007c), carmoisine A (Gupta et al. 2009b), blue 113 (Gupta et al. 2011c), metanil yellow (Mittal et al. 2008), safranin T (Gupta et al. 2007b), crystal violet (Gupta et al. 2010a), phenol red (Gupta et al. 2009a), and triaryl methane (Gupta et al. 2010b). Waste (Gupta et al. 2007a; Jain et al. 2004, 2003), activated carbon (Gupta et al. 1998; Karthikeyan et al. 2012), carbon nanotubes (Gupta et al. 2011a, b), and specific columns (Gupta et al. 2012b) are used in many technologies.

In this paper, the influence of biopolymers, such as albumins: bovine serum albumin (BSA), ovalbumin (OVA), 
and human serum albumin (HSA), on the stability of the chromium(III) oxide suspension was examined. $\mathrm{Cr}_{2} \mathrm{O}_{3}$ was used in the experiments because of its wide industry application. This is a dark green, amphoteric, sparingly water-soluble solid, as well as the most stable green dye used in glass and ceramic industries, construction, painting, etc. (Barnhart 1997; Gattens and Stout 1966; Patnaik 2002). In recent years, $\mathrm{Cr}_{2} \mathrm{O}_{3}$ is tested for the catalytic properties (Kantserova et al. 2009) as well as its ability to increase the collagen stability (Sangeetha et al. 2012). Due to the adverse effects of chromium(III) oxide on organisms in aquatic ecosystems, the search for effective methods of its removal from aqueous solutions is fully justified. $\mathrm{Cr}_{2} \mathrm{O}_{3}$ contributes to reducing the efficiency of photosynthesis and thus other vital processes occurring in water (ŚwiderskaBróż 1993). Several methods of chromium and other metal removal from aqueous solutions have been described in the literature (Gupta et al. 2010c, 2012c; Gupta and Sharma 2003; Saleh et al. 2011; Gupta and Rastogi 2009).

Albumins were selected for the study due to their important functions in organisms and wide use in many scientific areas. Bovine serum albumin is a protein composed of 583 amino acids, obtained on a large scale from cow blood. BSA is used in molecular biology and biotechnology as a stabilizing agent in buffers, protein for a standard curve as well as nutrient in cell cultures. The described protein does not possess enzymatic properties (Yamane et al. 1975; Wright and Thompson 1975). Ovalbumin is the main protein component of egg yolk. It consists of 385 amino acids. Due to its high availability, OVA is used in the studies of protein structure and properties as well as in immunology as a factor stimulating allergic reaction (Huntington and Stein 2001; Baynes and Dominiczak 2005). Human serum albumin is the predominant protein in human serum, consisting of 585 amino acids. It is produced in the kidney and performs an important function in the human body, inter alia, it maintains the osmotic pressure on a constant level and is involved in the transport of hormones, fatty acids, and drugs. Because of remarkable HSA role and its wide use in clinical cases, the method of HSA synthetic equivalent preparation is being developed (Karlsson et al. 2010; Roche et al. 2008). Perhaps, the results presented in this study could be helpful in achieving the above objective.

As it was mentioned above, in this paper, the stability mechanism of chromium(III) oxide suspension in the absence and presence of albumins was proposed. The main aim of the study was to determine whether the selected biopolymers cause suitable changes in the $\mathrm{Cr}_{2} \mathrm{O}_{3}$ suspension stability. The research team wanted to test whether the albumin presence helps or hinders the metal oxide removal from aqueous solutions. The studies on efficient removal of colorful contaminants from water and wastewater are particularly important because of the constant population problem with access to drinking water. Thus, the stability mechanism of the $\mathrm{Cr}_{2} \mathrm{O}_{3}$ suspension in the presence of various polymers, i.e., ionic polyamino acids (Ostolska and Wiśniewska 2014), Sinorhizobium meliloti 1021 exopolysaccharide (Szewczuk-Karpisz et al. 2014), and polyacrylic acid (Wiśniewska and Szewczuk-Karpisz 2013), has been investigated.

It should be also noted that the examination of metal oxide suspension stability in the protein presence can certainly be regarded as innovative. There are few studies on this subject in the literature. Wells et al. (2011) described the stability of iron(III) and zinc oxide nanoparticle suspensions in the serum protein presence, and Szekeres et al. (2013) determined the modified magnetite suspension stability. However, their main purpose was to check the possibility of medical applications. Moreover, the method used for stability measurements of the $\mathrm{Cr}_{2} \mathrm{O}_{3}$ and $\mathrm{Cr}_{2} \mathrm{O}_{3}-$ albumin systems is very modern. The calculated Turbiscan Stability Index (TSI) parameter accurately determines the suspension stability.

\section{Materials and methods}

Experiments design and sampling preparation

Chromium(III) oxide (POCh) of the specific surface area equal to $7.12 \mathrm{~m}^{2} / \mathrm{g}$ was used as the adsorbent in the experiments (Table 1). The metal oxide-specific surface area as well as average pore diameter was determined based on the analysis of nitrogen adsorption-desorption isotherms (BET method). The average size of the $\mathrm{Cr}_{2} \mathrm{O}_{3}$ particles was measured using a Zetasizer (Szewczuk-Karpisz and Wiśniewska 2014). The adsorbent was washed out from inorganic ions using redistilled water to the conductivity $<3 \mathrm{mS} / \mathrm{cm}$. Then, it was dried and crushed in a porcelain crucible.

Bovine serum albumin (BSA), ovalbumin (OVA), and human serum albumin (HSA) (Sigma-Aldrich) were used in the experiments as adsorbates (Table 2). As reported in the literature, the BSA molecular weight is $66.43 \mathrm{kDa}$ (Hirayama et al. 1990) and its isoelectric point (pI) is in the range 4.7-4.9 (Dawson et al. 1993; Malamud and Drysdale 1978). In turn, the HSA molecular weight is 66.248 (Putnam 1975) or $66.437 \mathrm{kDa}$ (Meloun et al. 1975), and its isoelectric point is equal to 4.7 (Putnam 1975). Due to high amino acid sequence similarity (76\%), bovine serum albumin and human serum albumin are considered as homologues. BSA and HSA molecules are approximately heart-shaped in the pH range 4-8 (Carter and Ho 1994). Ovalbumin is a protein with the mass of $42.7 \mathrm{kDa}$ (Nisbet et al. 1981) and the isoelectric point in the range 4.43-4.9 
Table 1 Chromium(III) oxide parameters

\begin{tabular}{lllll}
\hline Adsorbent & & $S_{\mathrm{BET}}\left(\mathrm{m}_{2} / \mathrm{g}\right)$ & $D(\mathrm{~nm})$ & $D_{\mathrm{p}}(\mathrm{A})$ \\
\hline Chromium(III) oxide & $\mathrm{Cr}_{2} \mathrm{O}_{3}$ & 7.12 & 265 & 93.25 \\
& & $\mathrm{Crr}$ & & \\
\hline
\end{tabular}

$S_{\mathrm{BET}}$ specific surface area, $D$ average particle size, $D_{\mathrm{p}}$ average pore diameter

Table 2 Albumin characteristics

\begin{tabular}{lll}
\hline Adsorbates & $\mathrm{M}(\mathrm{kDa})$ & $\mathrm{pI}$ \\
\hline Bovine serum albumin (BSA) & 66.43 & $4.7-4.9$ \\
Human serum albumin (HSA) & 66.248 or 66.437 & 4.7 \\
Ovalbumin (OVA) & 42.7 & $4.43-4.9$ \\
\hline
\end{tabular}

(Beeley et al. 1972; Kidwai et al. 1976). Due to the OVA amino acid sequence and spatial structure, it was classified as serpin (Gettins 2002).

The chromium(III) oxide suspensions for stability measurements were prepared by adding $0.02 \mathrm{~g}$ of the adsorbent to $20 \mathrm{ml}$ of electrolyte solution $(0.01 \mathrm{M} \mathrm{NaCl})$. On the other hand, suspensions containing adsorbates were prepared by adding the identical portion of the solid to the solution containing $0.01 \mathrm{M} \mathrm{NaCl}$. After albumin addition (100 ppm) and adjusting the suspension $\mathrm{pH}(3,4.6,7.6$ or $9)$, the examined system was transferred to a glass vial and the measurement was started in a constant temperature chamber $\left(25^{\circ} \mathrm{C}\right)$.

The samples for zeta potential measurements were prepared by adding $0.03 \mathrm{~g}$ of the solid to $500 \mathrm{ml}$ of $0.01 \mathrm{M}$ $\mathrm{NaCl}$ solution. Suspensions containing biopolymers were prepared by the addition of identical metal oxide portion to the solution containing $0.01 \mathrm{M} \mathrm{NaCl}$ and 10, 50, 100, 300, or $500 \mathrm{ppm}$ of albumin. After 3-min sonication, the samples were poured into five Erlenmeyer flasks and their $\mathrm{pH}$ values $(3,4.6,6,7.6$ and $9 \pm 0.05)$ were adjusted using $0.01 \mathrm{M} \mathrm{HCl}$ and $0.01 \mathrm{M} \mathrm{NaOH}$. The measurement system was washed twice with distilled water before each measurement.

\section{Analytical methods}

Stability measurements of the chromium(III) oxide suspension in the absence and presence of albumin were performed by using a turbidimeter Turbiscan Lab ${ }^{\text {Expert }}$ with the cooling module TLAb Cooler. The results were obtained as the curves of transmission and backscattering of light $(\lambda=880 \mathrm{~nm})$ passing through the sample and the TSI values. A single stability measurement lasted $3 \mathrm{~h}$, during which relevant data were recorded every $5 \mathrm{~min}$. The
TSI value was calculated by the computer software working with the turbidimeter on the basis of the following formula:

$\mathrm{TSI}=\sqrt{\frac{\sum_{i=1}^{n}\left(x_{i}-x_{\mathrm{BS}}\right)^{2}}{n-1}}$

where $x_{i}$ average backscatter for every minute of measurement, $x_{\mathrm{BS}}$ average $x_{i}, n$ number of scans.

The electrokinetic potential of the chromium(III) oxide particles in the absence and presence of albumin was measured by a zetameter Zetasizer 3000 from Malvern Instruments. The above apparatus determines the zeta potential of colloidal particles moving in electric field on the steady level of electrophoretic cell. The potential reading is made automatically when the particle movement is compensated for by the applied voltage. According to Smoluchowski, the speed $(u)$ of the colloidal particles moving in the electric field is associated to the zeta potential ( $\zeta)$ by the equation:

$\zeta=\frac{\alpha u}{D F} \eta$

where $\alpha$ factor depending on the particle shape (for spherical particles $\alpha=6 \pi$ for cylindrical $\alpha=4 \pi$ ); $D$ dielectric constant; $F$ electric field strength; $\eta$ viscosity.

Statistical analysis

One result of zeta potential was the average of five measurements. The measurement error was calculated as the standard deviation. The obtained values did not exceed $5 \%$.

\section{Results and discussion}

Stability of the chromium(III) oxide suspension in the absence and presence of albumin

The stability of the chromium(III) oxide suspension in the absence and presence of albumin was measured using a turbidimeter. The results were obtained in the form of the curves of transmission and backscattering of light beam 
passing through the sample as well as the TSI values. The graphs for the $\mathrm{Cr}_{2} \mathrm{O}_{3}$ and $\mathrm{Cr}_{2} \mathrm{O}_{3}-\mathrm{BSA}$ systems at $\mathrm{pH} 3$ and 7.6 are shown in Figs. 1 and 2. The results obtained for OVA and HSA are not presented because they are very similar to those for BSA. The TSI values are summarized in Table 3.

Based on the obtained results, it was stated that the $\mathrm{Cr}_{2} \mathrm{O}_{3}$ suspension stability depends on the solution $\mathrm{pH}$ (Ostolska and Wiśniewska 2014; Wiśniewska and Szewczuk-Karpisz 2013). Thus, among the examined systems, the metal oxide suspension is characterized by the highest stability at $\mathrm{pH} 3$ and 9 . This is evidenced by the relatively low TSI values (34.8 and 34.22, respectively) and also low, in comparison with other systems, transmission level of light (in both cases approximately $25 \%$ in the last minutes of the measurement). At $\mathrm{pH} 4.6$, the system is slightly less stable than at $\mathrm{pH} 3$ and 9 (TSI $=36.6$ ). On the other hand, the $\mathrm{Cr}_{2} \mathrm{O}_{3}$ suspension has the lowest stability at $\mathrm{pH}$ 7.6. The proof is the high TSI value (55.43) and high transmission level ( $52 \%$ in the last minutes of measurement). The presented results correspond to the data published by Ostolska and Wiśniewska (2014). Moreover, they are similar to those obtained during the stability examination of $\mathrm{Cr}_{2} \mathrm{O}_{3}$ suspension in the PAA presence (Wiśniewska and Szewczuk-Karpisz 2013).

The albumin addition, regardless of its type and solution $\mathrm{pH}$, increases the chromium(III) oxide suspension stability. This phenomenon is equivalent to the drop in the TSI value (for example, for BSA at pH 3-25.9), the backscatter level increase (for BSA at $\mathrm{pH} 3$ from 10 to $18 \%$ in the last minutes of the measurement) and the decrease in transmission level (for BSA at $\mathrm{pH} 3$ from 25 to $12 \%$ in the last minutes of the measurement). A similar serum protein effect was observed during the study of inorganic compounds, i.e., $\mathrm{TiO}_{2}$ (Allouni et al. 2009; Meißner et al. 2009; Vamanu et al. 2008), $\mathrm{Fe}_{2} \mathrm{O}_{3}$ and $\mathrm{ZnO}$ (Wells et al. 2011), WC (Meißner et al. 2009), and fullerene (Deguchi et al. 2007). On the other hand, Flynn et al. (2012) claimed that
Fig. 1 Transmission and backscatter curves for the chromium(III) oxide suspensions as a function of solution $\mathrm{pH}$ : a $\mathrm{pH} 3, \mathbf{b} \mathrm{pH}$ 7.6. $\mathrm{C}_{\mathrm{NaCl}}=0.01 \mathrm{M}$ (a)

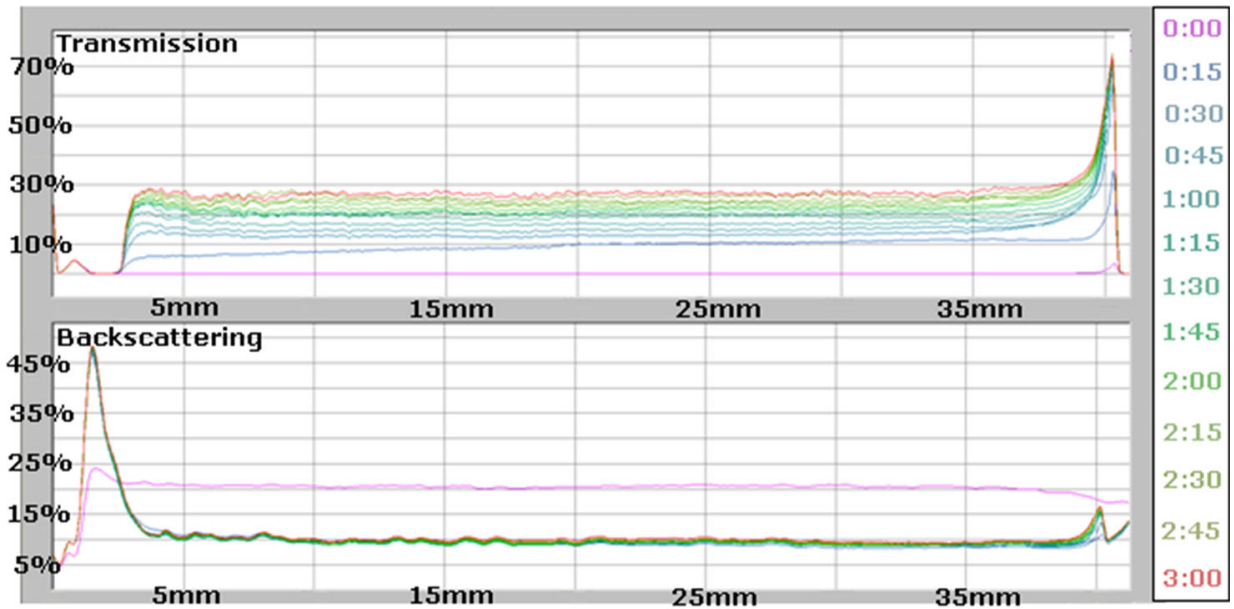

(b)

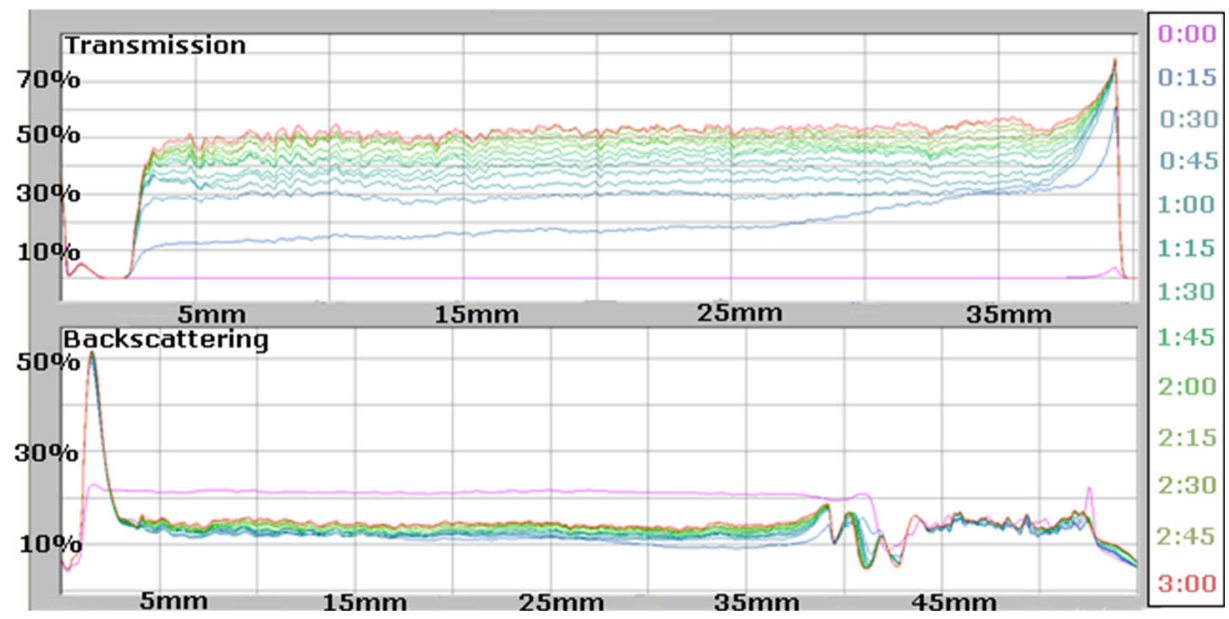


Fig. 2 Transmission and backscatter curves for the systems: $\mathbf{a} \mathrm{Cr}_{2} \mathrm{O}_{3}-\mathrm{BSA}$ at $\mathrm{pH} 3$, b $\mathrm{Cr}_{2} \mathrm{O}_{3}-\mathrm{BSA}$ at $\mathrm{pH}$ 7.6.

$\mathrm{C}_{\mathrm{BSA}}=100 \mathrm{ppm}$,

$\mathrm{C}_{\mathrm{NaCl}}=0.01 \mathrm{M}$

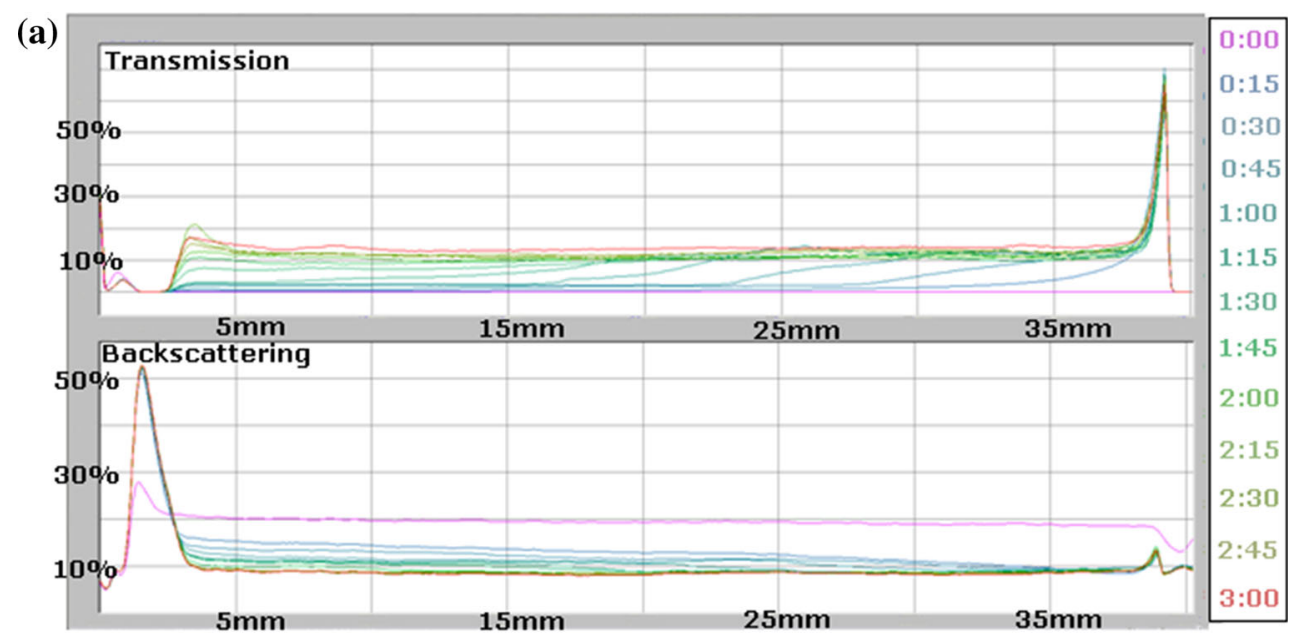

(b)

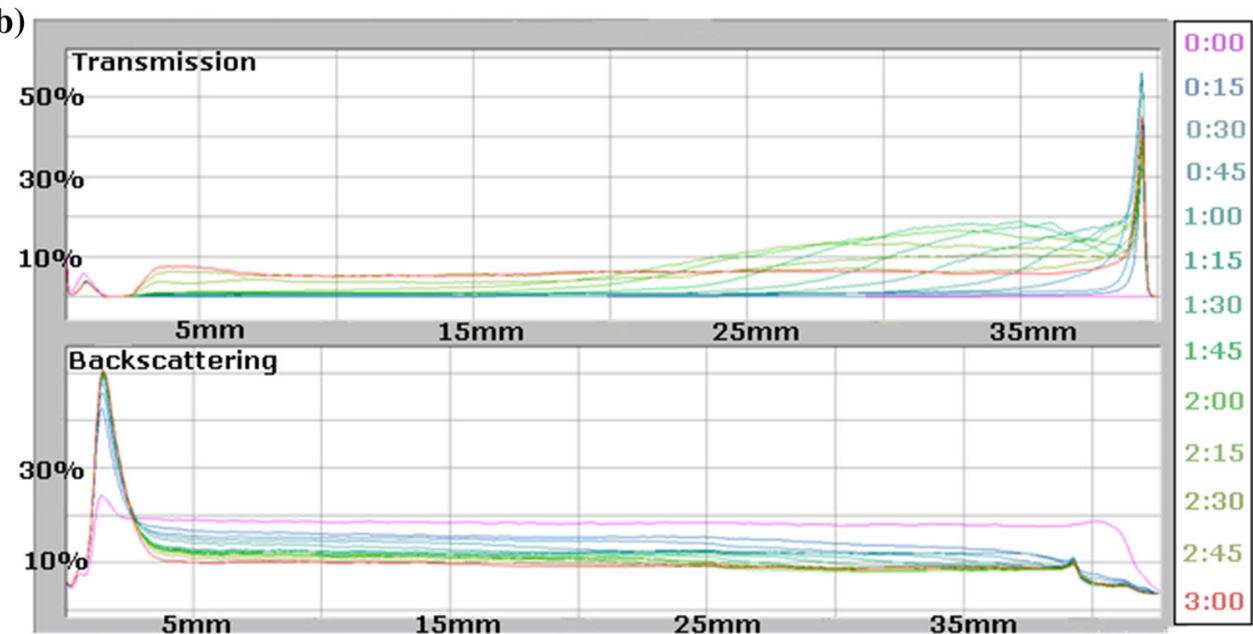

Table 3 Turbiscan Stability Index (TSI) values for chromium(III) oxide suspension in the absence and presence of albumins (100 ppm) calculated on the basis of data obtained at $15 \mathrm{~h}$ using Eq. (1)

\begin{tabular}{lllll}
\hline System & \multicolumn{4}{l}{ Turbiscan Stability Index (TSI) } \\
\cline { 2 - 5 } & $\mathrm{pH} \mathrm{3}$ & $\mathrm{pH} \mathrm{4.6}$ & $\mathrm{pH} \mathrm{7.6}$ & $\mathrm{pH} \mathrm{9}$ \\
\hline $\mathrm{Cr}_{2} \mathrm{O}_{3}$ & 34.8 & 36.6 & 55.43 & 34.22 \\
$\mathrm{BSA}-\mathrm{Cr}_{2} \mathrm{O}_{3}$ & 25.91 & 24.55 & 18.82 & 17.55 \\
$\mathrm{OVA}-\mathrm{Cr}_{2} \mathrm{O}_{3}$ & 30.0 & 25.27 & 22.11 & 17.56 \\
$\mathrm{HSA}-\mathrm{Cr}_{2} \mathrm{O}_{3}$ & 19.8 & 24.09 & 14.33 & 18.82 \\
\hline
\end{tabular}

BSA presence slightly reduces electrostatic repulsion between colloid particles, which is equivalent to a slight stability decrease.

Electrokinetic potential of the chromium(III) oxide particles in the absence and presence of albumin

The electrokinetic potential ( $\zeta$ ) of the chromium(III) oxide particles was measured in the absence and presence of albumin. The obtained values are shown in Figs. 3 and 4. The graphs for OVA and HSA are not presented due to a high similarity to the BSA one.

The result analysis showed that the isoelectric point $\left(\mathrm{pH}_{\mathrm{iep}}\right)$ of chromium(III) oxide is approximately six. At $\mathrm{pH}$ values above this value, negatively charged groups dominate in the slip plane of the metal oxide, whereas below this value-positively charged groups. The albumin presence, regardless of its type and concentration, shifts the $\mathrm{Cr}_{2} \mathrm{O}_{3} \mathrm{pH}_{\text {iep }}$ point to a more acidic value, i.e., about five, which corresponds to the adsorbate isoelectric point. Thus, it can be assumed that at specific albumin concentrations (10-500 ppm), the $\mathrm{Cr}_{2} \mathrm{O}_{3}$ particles are completely covered with the albumin macromolecules and the adsorbent surface charge is totally masked. Then, the adsorbed biopolymer macromolecules give the $\mathrm{Cr}_{2} \mathrm{O}_{3}$ surface such chemical properties which are characteristic of the albumin. The described albumin adsorption influence on the metal oxide $\mathrm{pH}_{\mathrm{iep}}$ value correspond to the data published by Rezwan et al. (2004, 2005) working on BSA and 


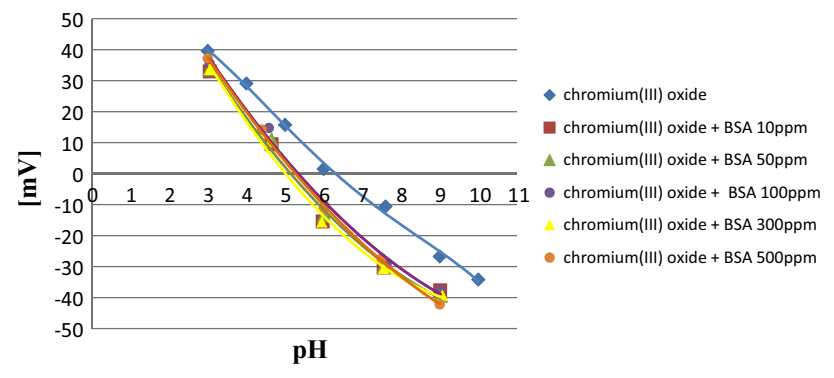

Fig. 3 Electrokinetic potential of the $\mathrm{Cr}_{2} \mathrm{O}_{3}$ particles in the absence and presence of BSA. The results for OVA and HSA were similar

lysozyme. Moreover, Hindber et al. (1996) observed that also the adsorption of a small molecule, i.e., citric acid, shifts the alumina $\mathrm{pH}_{\text {iep }}$ point to the $\mathrm{pK}$ value of citric acid.

The albumin adsorption amount on the $\mathrm{Cr}_{2} \mathrm{O}_{3}$ surface was measured on the basis of differences in the protein concentration in solution before and after the process (Szewczuk-Karpisz and Wiśniewska 2014). The results are shown in Fig. 5. Their analysis showed that the adsorption amount varies with the solution $\mathrm{pH}$. This is associated with the conformation changes of the biopolymer macromolecules. At the isoelectric point, albumins have the most compact coil structure (in the case of BSA the $\alpha$-helix content is equal to $55 \%$ Foster 1977), which enables the adsorption of the largest macromolecule number on the unit adsorbent surface. Moving away from the $\mathrm{pI}$ value is equivalent to gradual expansion of their conformation. At $\mathrm{pH} \mathrm{3,} \mathrm{macromolecules} \mathrm{adopt} \mathrm{the}$ most expanded structure (for BSA the $\alpha$-helix content is about $35 \%$ Foster 1977), which contributes to the lowest adsorption level under these conditions. However, the obtained electrokinetic potential values showed that despite the differences in the albumin conformation at different solution $\mathrm{pH}$ values, in each test case, the adsorbent surface is completely covered with the albumin macromolecules. This is evidenced by the $\mathrm{Cr}_{2} \mathrm{O}_{3} \mathrm{pH}_{\text {iep }}$ value in the albumin presence which is close to the $\mathrm{pI}$ value of pure adsorbates.

The analysis of the zeta potential values also showed that the albumin adsorption on the metal oxide surface reduces the solid particle zeta potential in the whole $\mathrm{pH}$ range. In the interpretation of electrokinetic properties of the synthetic polymer/metal oxide system, this decrease is explained by the slipping plane offset by the adsorbed macromolecules (Wiśniewska and Szewczuk-Karpisz 2013). Perhaps, the adsorption of the biopolymer macromolecules, such as albumin, is also related to a similar phenomenon. Furthermore, the dissociated functional

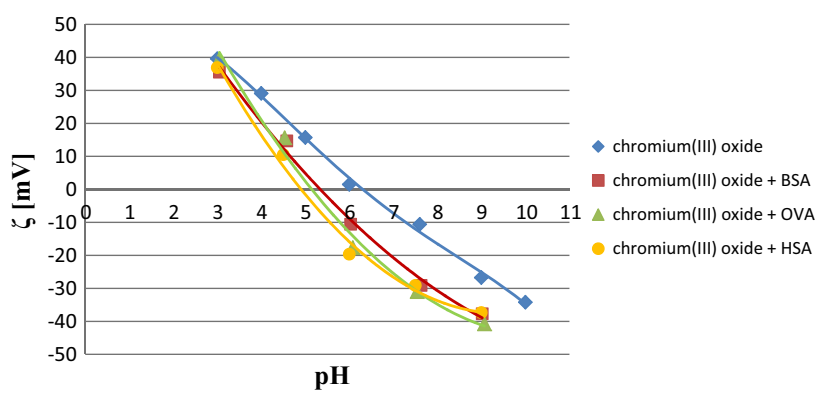

Fig. 4 Electrokinetic potential of the $\mathrm{Cr}_{2} \mathrm{O}_{3}$ particles in the absence and presence of albumins with the concentration of $100 \mathrm{ppm}$

carboxylic groups derived from acidic amino acids present in the albumin macromolecules may be responsible for the electrokinetic potential reduction. They are mainly located in the parts that do not directly interact with the solid surface. Charge distribution in the BSA and HSA macromolecules was presented by Rezwan et al. (2004).

It should be also noted that the reduction of the $\mathrm{Cr}_{2} \mathrm{O}_{3}$ electrokinetic potential is very similar for the three studied albumins (BSA, OVA and HSA) (Fig. 4). This is probably associated with similar properties of the adsorbates, including their acidic nature and approximated values of the isoelectric point.

\section{Stabilization/destabilization mechanism}

of the chromium(III) oxide suspension in the absence and presence of albumin

Knowledge of the albumin adsorption amount on the chromium(III) oxide surface, the stability, and electrokinetic properties of the examined systems makes determination of the probable stability mechanism of the $\mathrm{Cr}_{2} \mathrm{O}_{3}$ suspension in the absence and presence of albumin possible.

Thus, the chromium(III) oxide suspension without albumin is the most stable at $\mathrm{pH} 3$ and 9, which correspond to the results obtained by Ostolska and Wiśniewska (2014). This is mainly due to the electrostatic repulsion occurring between the solid particles, which are surrounded by the ions of the supporting electrolyte $(\mathrm{NaCl})$ charged oppositely to the solid surface. The previous measurements of the surface charge density of chromium(III) oxide carried out using the potentiometric titration method showed that the $\mathrm{pH}_{\mathrm{pzc}}$ (the point of zero charge) of the metal oxide is about 7.6 (Szewczuk-Karpisz and Wiśniewska 2014). Thus, at pH 3, the solid particles are positively charged and the sheath around them is formed by chloride ions. In contrast, at $\mathrm{pH} \mathrm{9,} \mathrm{the}$ 

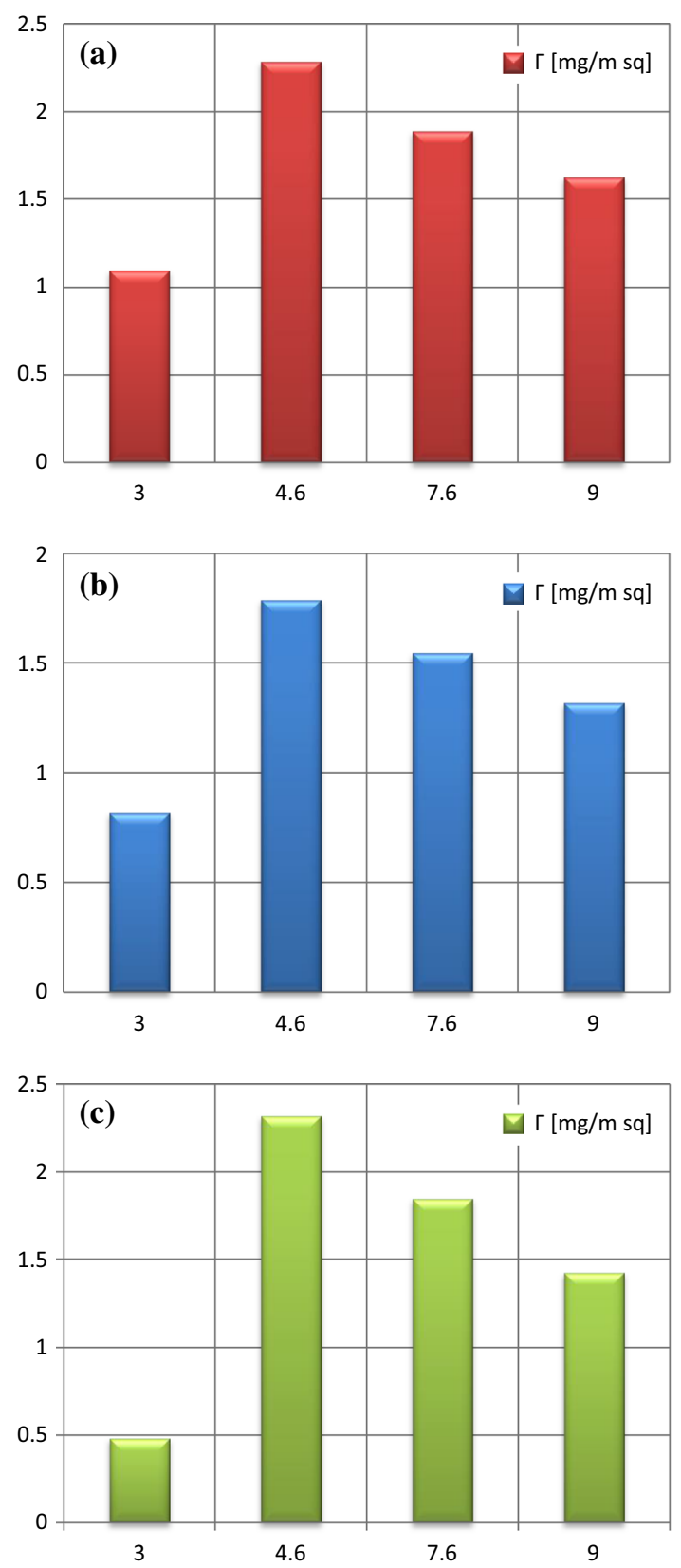

Fig. 5 The albumin amount adsorbed on the $\mathrm{Cr}_{2} \mathrm{O}_{3}$ particles as a function of solution $\mathrm{pH}$ : a BSA, b OVA, c HSA. $\mathrm{C}_{\text {albumin }}$ (initial) $=250 \mathrm{ppm}$

$\mathrm{Cr}_{2} \mathrm{O}_{3}$ particles are negative and the sheath around them is made by sodium ions. The observed values of the solid electrokinetic potential at $\mathrm{pH} 3$ and 9 (40 and $-22 \mathrm{mV}$, respectively) are the result of this phenomena. Smaller stability of the system at $\mathrm{pH} 4.6$ as compared to $\mathrm{pH} 3$ is associated with the smaller zeta potential value of the

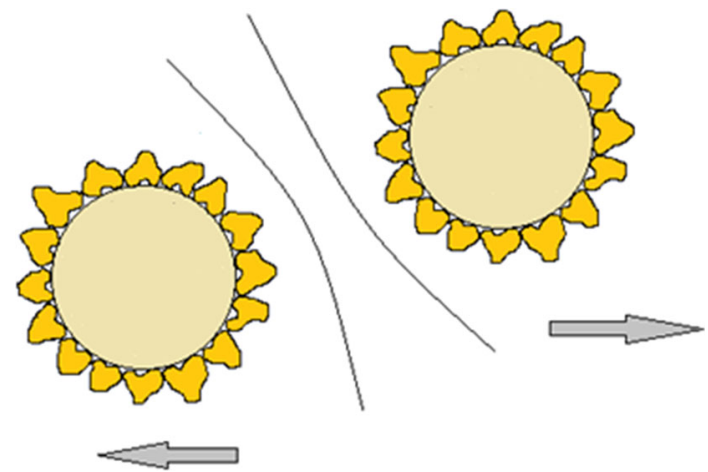

Fig. 6 Stabilization mechanism of the $\mathrm{Cr}_{2} \mathrm{O}_{3}$ suspension by albumins

metal oxide (about $20 \mathrm{mV}$ ) and thus with the weaker electrostatic repulsion between the particles. Thus, it can be concluded that the relatively high stability of the

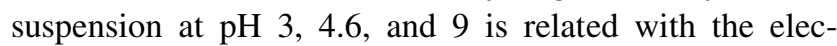
trostatic stabilization phenomenon, which limits the particle collision and the formation of solid aggregates.

The chromium(III) oxide suspension without albumin is the least stable at pH 7.6. The low stability of the system under these conditions is primarily due to the zero surface charge of the metal oxide, and thus, no electrostatic repulsion between the particles is found.

The albumin addition, regardless of their type and solution $\mathrm{pH}$, increases the $\mathrm{Cr}_{2} \mathrm{O}_{3}$ suspension stability. Biopolymer macromolecules adsorb onto the metal oxide surface in each test solution $\mathrm{pH}$, the greatest amount adsorbed at $\mathrm{pH} 4.6$ (a value close to the isoelectric point of the adsorbate) and the lowest at $\mathrm{pH} 3$. The increase in the suspension stability in the albumin presence is evidenced by both the TSI values and the increase in backscatter and the decrease in transmission of light passing through the examined systems. During the analysis of the obtained adsorption amount and the $\mathrm{Cr}_{2} \mathrm{O}_{3}$ zeta potential values, it was found that in the whole $\mathrm{pH}$ range, the solid particle surface is completely covered with the biopolymer macromolecules. Thus, the most likely mechanism of stabilization suspension, which contributes to increase in stability of the tested systems, is the steric stabilization (Kraynov and Muller 2011). It is due to the mutual repulsion of the adsorption layers formed on the solid surface. Increase in the $\mathrm{Cr}_{2} \mathrm{O}_{3}$ suspension stability in the albumin presence is equivalent to even more difficult formation of solid particle aggregates, which is highly undesirable in the procedure of wastewaters treatment.

The proposed mechanism of the chromium(III) oxide suspension stabilization in the albumin presence is shown 
schematically in Fig. 6 (for BSA at pH 7.6 using the model developed by Rezwan et al. 2004).

\section{Conclusion}

The pooled result analysis allowed to draw the following conclusions: (1) the isoelectric point $\left(\mathrm{pH}_{\mathrm{iep}}\right)$ of chromium(III) oxide is about 6 , (2) the albumin presence, regardless of their type, in the concentration range of 10-500 ppm, shifts the $\mathrm{Cr}_{2} \mathrm{O}_{3} \mathrm{pH}_{\text {iep }}$ point to 5, (3) the isoelectric point of chromium(III) oxide in the albumin presence is close to the isoelectric points of the pure adsorbates, which shows that the adsorbent surface is fully coated with the biopolymer macromolecules, (4) the $\mathrm{Cr}_{2} \mathrm{O}_{3}$

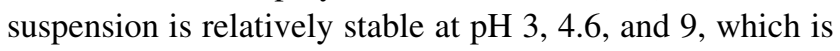
connected with the electrostatic stabilization phenomenon, (5) the metal oxide suspension is the least stable at $\mathrm{pH}$ 7.6, which is associated with the adsorbent zero surface charge, and (6) the albumin presence causes the increase in the $\mathrm{Cr}_{2} \mathrm{O}_{3}$ suspension stability in the whole $\mathrm{pH}$ range, which is connected with the steric stabilization phenomenon.

Thus, the presence of albumin in the industrial wastewaters is highly undesirable as it hinders the removal of chromium(III) oxide and probably other particles of colloidal dimensions.

Acknowledgments I would like to thank Professor Stanisław Chibowski, manager of Department of Radiochemistry and Colloid Chemistry UMCS, for enabling the implantation of the experimental works.

Open Access This article is distributed under the terms of the Creative Commons Attribution License which permits any use, distribution, and reproduction in any medium, provided the original author(s) and the source are credited.

\section{References}

Allouni ZE, Cimpan MR, Hol PJ, Skodvin T, Gjerdet NR (2009) Agglomeration and sedimentation of $\mathrm{TiO}_{2}$ nanoparticles in cell culture medium. Colloids Surf B 68:83-87

Barnhart J (1997) Occurances, uses and properties of chromium. Regul Toxicol Pharmacol 26:3-7

Baynes J, Dominiczak MH (2005) Medical biochemistry, 2nd edn. Mosby, St. Louis

Beeley JA et al (1972) Polyacrylamide gel isoelectric focusing of proteins: determination of isoelectric points using an antimony electrode. Biochim Biophys Acta 285:293-300

Carter DC, Ho JX (1994) Structure of serum albumin. Adv Protein Chem 45:153-203
Dawson RMC et al (1993) Data for biochemical research, 3rd edn. Clarendon Press, Oxford

Deguchi S, Yamazaki T, Mukai S, Usami R, Horikoshi K (2007) Stabilization of C60 nanoparticles by protein adsorption and its implication for toxicity studies. Chem Res Toxicol 20:854-858

Flynn RM, Yang X, Hofmann T, Von der Kammer F (2012) Bovine serum albumin adsorption to iron-oxide coated sands can change microsphere deposition mechanisms. Environ Sci Technol 46:2583-2591

Foster JF (1977) Albumin structure, function and uses. Pergamon Press, Oxford

Gattens RJ, Stout GL (1966) Painting materials: a short encyclopaedia. Dover Publications, New York

Gettins PGW (2002) Serpin structure, mechanism and function. Chem Rev 102(12):4751-4804

Gupta VK, Rastogi A (2009) Biosorption of hexavalent chromium by raw and acid-treated green alga Oedogonium hatei from aqueous solutions. J Hazard Mater 163(1):396-402

Gupta VK, Sharma S (2003) Removal of zinc from aqueous solutions using bagasse fly ash - a low cost adsorbent. Ind Eng Chem Res 42(25):6619-6624

Gupta VK, Srivasta SK, Mohan D, Sharma S (1998) Design parameters for fixed bed reactors of activated carbon developed from fertilizer waste for the removal of some heavy metal ions. Waste Manag 17(8):517-522

Gupta VK, Mittal A, Krishnan L, Mittal J (2006a) Adsorption treatment and recovery of the hazardous dye, brilliant blue FCF, over bottom ash and de-oiled soya. J Colloid Interface Sci 293(1):16-26

Gupta VK, Mittal A, Kurup L, Mittal J (2006b) Adsorption of a hazardous dye, erythrosine, over hen feathers. J Colloid Interface Sci 304(1):52-57

Gupta VK, Ali I, Saini VK (2007a) Deflueridation of wastewaters using waste carbon slurry. Water Res 41:3307-3316

Gupta VK, Jain R, Mittal A, Mathur M, Sikarwar S (2007b) Photochemical degradation of the hazardous dye Safranin-T using TiO catalyst. J Colloid Interface Sci 309(2):464-469

Gupta VK, Jain R, Varshney S (2007c) Electrochemical removal of hazardous dye reactiofix red $3 \mathrm{BFN}$ from industrial effluents. J Colloid Interface Sci 312(2):292-296

Gupta VK, Jain R, Varshney S (2007d) Removal of reactofix golden yellow 3 RFN from aqueous solution using wheat husk-an agricultural waste. J Hazard Mater 142(1-2):443-448

Gupta VK, Mittal A, Kaur D, Malviya A, Mittal J (2009a) Adsorption studies of the removal of colouring agent phenol red from wastewater using waste materials as adsorbents. J Colloid Interface Sci 337:345-354

Gupta VK, Mittal A, Malviya A, Mittal J (2009b) Adsorption of carmoisine A from wastewater using waste materials-bottom ash and deoiled soya. J Colloid Interface Sci 335:24-33

Gupta VK, Mittal A, Mittal J (2010a) Adsorption on hazardous dye crystal violet from wastewater by waste materials. J Colloid Interface Sci 343:463-473

Gupta VK, Mittal A, Mittal J (2010b) Decoloration treatment of a hazardous triatyl methane dye, light green SF (yellowish) by waste material adsorbents. $\mathbf{J}$ Colloid Interface Sci 342(2):518-527

Gupta VK, Rastogi A, Nayak A (2010c) Adsorption studies on the removal of hexavalent chromium from aqueous solution using a low cost fertilizer industry waste material. J Colloid Interface Sci 342(1):135-141 
Gupta VK, Agarwal S, Saleh TA (2011a) Chromium removal combining the magnetic properties of iron oxide with adsorption properties of carbon nanotubes. Water Res 45(6):2207-2212

Gupta VK, Agarwal S, Saleh TA (2011b) Synthesis and characterization of alumina-coated carbon nanotubes and their application for lead removal. J Hazard Mater 185(1):17-23

Gupta VK, Gupta B, Rastogi A, Agarwal A, Nayak A (2011c) A comparative investigation on adsorption performances of mesoporous activated carbon prepared from waste rubber tire and activated carbon for a hazardous azo dye-acid blue 113 . J Hazard Mater 186:891-901

Gupta VK, Ali I, Saleh TA, Nayak A, Agarwal S (2012a) Chemical treatment technologies for wastewater recycling-an overview. RSC Adv 2:6380-6388

Gupta VK, Ali I, Saleh TA, Nayak A, Agarwal S (2012b) Column with CNT/magnesium oxide composite for lead(II) removal from water. Environ Sci Pollut Res 19:1224-1228

Gupta VK, Ali I, Saleh TA, Siddigui MN, Agarwal S (2012c) Chromium removal form water by activated carbon developed from waste rubber tires. Environ Sci Pollut Res. doi:10.1007/ s11356-012-0950-9

Gupta VK, Jain R, Mittal A, Agarwal A, Sikarwar S (2012d) Photodegradation of toxic dye amaranth on $\mathrm{TiO}_{2} / \mathrm{UV}$ in aqueous suspensions. Mater Sci Eng C 32(1):12-17

Hindber PC, Graule TJ, Gauckler LJ (1996) Citric acid—a dispersant for aqueous alumina suspensions. J Am Ceram Soc 79:1857-1867

Hirayama K, Akashi S, Furuya M, Fukuhara K (1990) Rapid conformation and revision of the primary structure of bovine serum albumin by ESIMS and Frit-FAB LC/MS. Biochem Biophys Res Commun 173(2):639-646

Huntington JA, Stein PE (2001) Structure and properties of ovalbumin. J Chromatogr B 756(1-2):189-198

Jain AK, Gupta VK, Bhatnagar A, Suhas A (2003) A comparative study of adsorbents prepared from industrial wastes for removal of dyes. Sep Sci Technol 38(2):463-473

Jain AK, Gupta VK, Jain S, Suhas (2004) Removal of chlorophenols using industrial wastes. Environ Sci Technol 38:1195-1200

Kantserova MR, Grabovaya NV, Kolotilov SV, Orlik SN (2009) Effect of size and morphology of chromium(III) oxide nanoparticles on their catalytic properties in deep oxidation of methane. Theor Exp Chem 45(6):368-372

Karlsson BCG, Rosengren AM, Naslund I, Nicholls IA (2010) Synthetic human serum albumin Sudlow I binding site mimics. J Med Chem 53(22):7932-7937

Karthikeyan S, Gupta VK, Boopathy R, Titus A, Sekaran G (2012) A new approach for the degradation of aniline by mesoporous activated carbon as a heterogeneous catalyst: kinetic and spectroscopic studies. J Mol Liq 173:153-163

Kidwai SA et al (1976) Effect of succinylation (3-carboxypropionylation) on the conformation and immunological activity of ovalbumin. Biochem J 155:171-180

Kraynov A, Muller TE (2011) Concepts for the stabilization of metal nanoparticles in ionic liquids. In: Handy S. (ed) Applications of ionic liquids in science and technology, Middle Tennessee State University, USA

Malamud D, Drysdale JW (1978) Isoelectric points of proteins: a table. Anal Biochem 86:620-647

Meißner T, Potthoff A, Richter V (2009) Suspension characterization as important key for toxicological investigations. J Phys Conf Ser 170:012012

Meloun B, Moravek L, Kostka V (1975) Complete amino acid sequence of human serum albumin. FEBS Lett 58(1):134-137
Mittal A, Kurup (Krishnan) L, Gupta VK (2005) Use of waste materials-bottom ash and de-oiled soya as potential adsorbents for the lead removal. J Hazard Mater 117:171-178

Mittal A, Gupta VK, Malviya A, Mittal J (2008) Process development for removal and recovery of Metanil Yellow by adsorption on waste materials-Bottom Ash and De-Oiled Soya. J Hazard Mater 151(2-3):821-832

Mittal A, Mittal J, Malviya A, Gupta VK (2010) Removal and recovery of chrysoidine $\mathrm{Y}$ from aqueous solutions by waste materials. J Colloid Interface Sci 344(2):497-507

Nisbet AD et al (1981) The complete amino-acid sequence of hen ovalbumin. Eur J Biochem 115:335-345

Nowicki W (2005) This world-bulletin of the Polish Ecological Club. Dist Gt Pol 2:13-17

Ostolska I, Wiśniewska M (2014) Application of the zeta potential measurements to explanation of colloidal $\mathrm{Cr}_{2} \mathrm{O}_{3}$ stability mechanism in the ionic polyamino acids. Colloid Polym Sci 292:2453-2464

Patnaik P (2002) Handbook of inorganic chemicals. McGraw-Hill, New York

Putnam W (1975) The plasma proteins, vol I, 2nd edn. Academic Press, New York

Rezwan K, Meier LP, Rezwan M, Voros J, Textor M, Gaucler LJ (2004) Bovine serum albumin adsorption onto colloidal $\mathrm{Al}_{2} \mathrm{O}_{3}$ particles: a new model based on zeta potential and UV-vis measurements. Langmuir 20:10055-10061

Rezwan K, Meier LP, Geuckler LJ (2005) Lysozyme and bovine serum albumin on uncoated silica and $\mathrm{AlOOH}$-coated silica particles: the influence of positively and negatively charged oxide surface coatings. Biomaterials 26:4351-4357

Roche M, Rondeau P, Singh NR et al (2008) The antioxidant properties of serum albumin. FEBS Lett 582(13):1783-1787

Saleh TA, Agarwal S, Gupta VK (2011) Synthesis of MWCNT/MnO and their application for simultaneous oxidation of arsenite and sorption of arsenate. Appl Catal B Environ 106(1-2):46-53

Sangeetha S, Ramamoorthy U, Sreeram KJ, Nair BU (2012) Enhancing collagen stability through nanostructures containing chromium(III) oxide. Colloids Surf B Biointerfaces 100: $36-41$

Świderska-Bróż M (1993) Micropollutants of water and the possibility of their removal. Environ Prot 3:23-28

Szekeres M, Toth IY, Illes E, Hajdu A, Zupko I, Farkas K, Oszlanczi G, Tiszlavicz L, Tombacz E (2013) Chemical and colloidal stability of carboxylated core-shell magnetite nanoparticles designed for biomedical applications. Int $\mathrm{J}$ Mol Sci 14:14550-14574

Szewczuk-Karpisz K, Wiśniewska M (2014) Adsorption properties of the albumin-chromium(III) oxide system-effect of solution $\mathrm{pH}$ and inionic strength. Soft Mater 12(3):268-276

Szewczuk-Karpisz K, Wiśniewska M, Pac M, Choma A, Komianiecka I (2014) Shinorhizobium meliloti 1021 exopolysaccharide as a flocculant improving chromium(III) oxide removal from aqueous solutions. Water Air Soil Pollut 225:2052

Vamanu CI, Hol PJ, Allouni ZE, Elsayed S, Gjerdet NR (2008) Formation of potential titanium antigens based on protein binding to titanium dioxide nanoparticles. Int $\mathbf{J}$ Nanomedicine 3:69-74

Wells MA, Abid A, Kennedy IM, Barakat AI (2011) Serum proteins prevent aggregation of $\mathrm{Fe}_{2} \mathrm{O}_{3}$ and $\mathrm{ZnO}$ nanoparticles. Nanotoxicology. doi:10.3109/17435390.2011.623131

Wiśniewska M, Szewczuk-Karpisz K (2013) Removal possibilities of colloidal chromium(III) oxide from water using polyacrylic acid. Environ Sci Pollut Res Int 20:3657-3669 
Wright AK, Thompson MR (1975) Hydrodynamic structure of bovine serum albumin determined by transient electric birefringence. Biophys J 15:137-141
Yamane I, Murakami O, Kato M (1975) Role of bovine albumin in a serum-free suspension cell culture medium. Proc Soc Exp Biol Med 2(149):439-442 